\title{
Paleoceanography
}

\section{RESEARCH ARTICLE \\ 10.1002/2015PA002777 \\ Key Points: \\ Evidence for changes in subsurface circulation in the late Eocene equatorial Pacific from radiolarian-bound nitrogen isotope values}

- Radiolarian-bound N isotopes are a good archive of surface nitrogen

- Radiolarian-bound $\mathrm{N}$ isotope values decrease across the Eocene-Oligocene boundary

- Climate-related ecological changes are likely responsible for the observed shift

Correspondence to:

R. S. Robinson,

rebecca_r@uri.edu

\section{Citation:}

Robinson, R. S., T. C. Moore, A. M. Erhardt, and H. D. Scher (2015), Evidence for changes in subsurface circulation in the late Eocene equatorial Pacific from radiolarian-bound nitrogen isotope values, Paleoceanography, 30, 912-922, doi:10.1002/2015PA002777.

Received 7 JAN 2015 Accepted 30 JUN 2015 Accepted article online 2 JUL 2015 Published online 20 JUL 2015

\author{
Rebecca S. Robinson ${ }^{1}$, Theodore C. Moore ${ }^{2}$, Andrea M. Erhardt ${ }^{3}$, and Howie D. Scher ${ }^{4}$ \\ ${ }^{1}$ Graduate School of Oceanography, University of Rhode Island, Kingston, Rhode Island, USA, ${ }^{2}$ Department of Earth and \\ Environmental Sciences, University of Michigan, Ann Arbor, Michigan, USA, ${ }^{3}$ Department of Earth Sciences, University of \\ Cambridge, Cambridge, UK, ${ }^{4}$ Department of Earth and Ocean Sciences, University of South Carolina, Columbia, South \\ Carolina, USA
}

Abstract Microfossil-bound organic matter represents an important archive of surface ocean environmental information. Sedimentary nitrogen $(\mathrm{N})$ isotope reconstructions of surface nitrate consumption and nitrogen source changes are made using fossil diatom (autotrophs) and planktic foraminiferal (heterotrophs)-bound organic matter with success. However, because diatoms and planktic foraminifera are poorly preserved and sedimentary organic matter content is near zero during the late Eocene, our ability to examine nutrient dynamics across this important climate transition is limited. Here we present new data exploring the use of $\mathrm{N}$ isotope records from radiolarian tests. A comparison of surface ocean nitrate and core top bulk and radiolarian $\mathrm{N}$ isotope values (as $\delta^{15} \mathrm{~N}$ ) from the equatorial Pacific indicates that radiolarian- $\mathrm{N}$ records $\delta^{15} \mathrm{~N}$ variability with fidelity but that a significant offset exists between bulk sedimentary and diatom $\delta^{15} \mathrm{~N}$ values and those measured from radiolarians $\left(\sim 7.1 \pm 1.1 \%\right.$ o). A downcore profile of radiolarian $\delta^{15} \mathrm{~N}$ values is compared to siliceous microfossil assemblage changes across the Eocene-Oligocene boundary. Average of radiolarian-bound $\delta^{15} \mathrm{~N}$ values is $0.5 \pm 2.0 \%$, which, when corrected using the offset derived from the modern surface samples, suggests that the mean nitrogen isotopic composition of the early Cenozoic eastern Pacific was not significantly different from today. The overall trend, of decreasing $\delta^{15} \mathrm{~N}$ values with decreasing export productivity, is consistent with either a regional decline in pelagic denitrification or a large-scale change in nutrient sources to the eastern equatorial Pacific (EEP), both linked to the cooling climate and changing intermediate water circulation. Decreasing/low $\delta^{15} \mathrm{~N}$ values cooccur with high radiolarian species turnover at $\sim 35.5$ and $34 \mathrm{Ma}$, suggestive of a significant ecological change in the EEP, consistent with cooling and water mass distribution changes. The preliminary results suggest that radiolarian-bound organic nitrogen represents another promising archive and underscores the fact that the different microfossil fractions must be separated to ensure robust results.

\section{Introduction}

\subsection{Motivation for a Radiolarian-Bound N Isotope Proxy}

Sedimentary nitrogen isotope records provide important information about the fundamental operation of the marine nitrogen cycle, the source of nitrate supporting photosynthesis, and in nutrient-replete settings, the degree of consumption by phytoplankton [Altabet and Francois, 1994; Francois et al., 1997; Galbraith et al., 2008]. Microfossil-bound organic matter represents an important archive of this surface ocean environmental information [Ren et al., 2009; Robinson et al., 2004; Sigman et al., 1999]. Nitrogen (N)-bearing organic molecules used by organisms during test formation become encapsulated by the biomineral (biogenic silica or calcium carbonate) and appear largely protected from alteration during sinking and sedimentation. Radiolarian tests are a robust fossil component of low-latitude seafloor sediment that extend beyond the diatom record in time and are persistent below the calcite compensation depth (CCD). Although radiolarian fossils have not yet been used as an organic nitrogen archive, we anticipated that they would integrate the isotopic signal of the sinking flux, analogous to foraminifera tests [Ren et al., 2009, 2013; Straub et al., 2013]. This paper presents a preliminary evaluation of the use of organic compounds bound within radiolarian tests as an archive of ancient organic nitrogen produced in the surface ocean. We focused on two central questions: (1) Does radiolarian $\mathrm{N}$ reflect the nitrogen isotopic composition of surface nitrate through their incorporation of sinking organic $\mathrm{N}$ produced in the surface ocean? (2) Is organic $\mathrm{N}$ preserved in ancient radiolarian tests buried in sediment? 

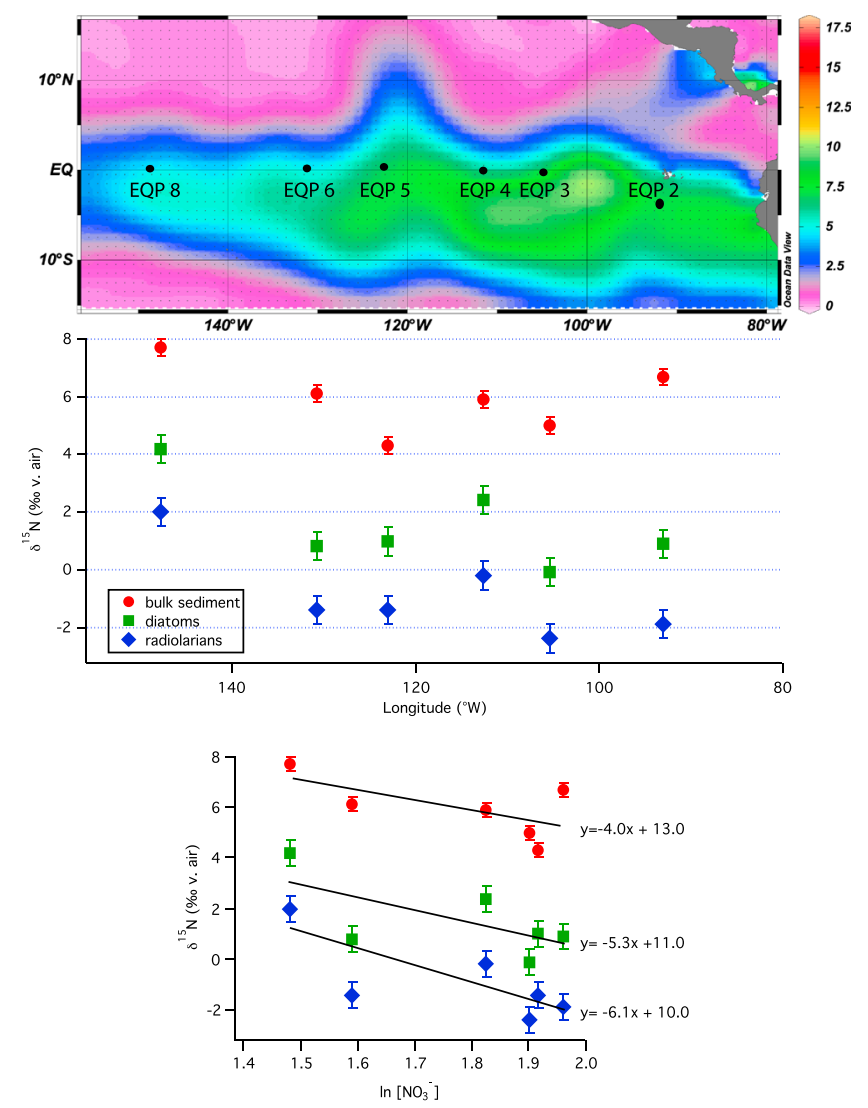

Figure 1. (top) Map of annual surface nitrate concentrations [Garcia et al., 2010] with cruise KNR 195-3 site locations overlain. Surface sediment bulk (red), diatom-bound $(<63 \mu \mathrm{m})$ (green), and radiolarian-bound $\delta{ }^{15} \mathrm{~N}$ $(>125 \mu \mathrm{m})$ (blue) values are plotted against (middle) latitude and (bottom) In $\left[\mathrm{NO}_{3}{ }^{-}\right]$(annual average). Error bars reflect the standard error of each measurement type. The isotope effects of nutrient uptake ( $\varepsilon$ values) estimated from the slopes of $\delta{ }^{15} \mathrm{~N} v$. In [NO3] (equations to right of plot) are in line with previous estimates from the EEP. The slightly higher $\varepsilon$ values for the microfossil-bound measurements suggest they may be more sensitive recorders of surface nutrient changes than bulk sediment.
The primary motivation for investigating radiolarian-bound $\mathrm{N}$ as an isotopic archive stems from their abundance in Eocene sediment and the potential to gain mechanistic information related to the chemical and ecological changes that occurred during the latest Eocene and earliest Oligocene. The onset of Antarctic glaciation, near the EoceneOligocene boundary, occurred as a stepwise transition toward the modern glacial climate state and was accompanied by significant global cooling, biotic turnover, and changes in weathering. It is hypothesized that the deteriorating Eocene climate, with falling atmospheric carbon dioxide $\left(p \mathrm{CO}_{2}\right)$ concentrations and orbital configurations that favored ice sheets growth, allowed for establishment of significant ice on Antarctica [DeConto and Pollard, 2003; DeConto et al., 2008]. A role for the carbon cycle in this transition is suggested by not only the $\mathrm{pCO}_{2}$ changes [Pagani et al., 2005; Pearson et al., 2009] but also a benthic carbon isotopic excursion of $\sim 1 \%$ [Coxall et al., 2005], the deepening of the CCD [Coxall et al., 2005; Palike et al., 2012], and increases in productivity in the Southern Ocean [DiesterHaass, 1995; Salamy and Zachos, 1999].

\subsection{Eocene-Oligocene Climate and Ecosystem Shifts}

Significant evidence exists for an overall decrease in export productivity from the upper Eocene into the lowermost Oligocene in the tropical Pacific [Erhardt et al., 2013; Griffith et al., 2010; Moore et al., 2014]. A productivity minimum during the earliest Oligocene glacial maximum (Oi-1) is apparent in records of barite and benthic foraminifera and opal accumulation rates. This reduction in export productivity was variously attributed to changes in ocean circulation, related to the cooling and enhanced stratification of the low-latitude oceans, a decrease in nutrient supply from the high latitudes, and/or decreased efficiency of remineralization in the cooler ocean. The idea of decreased remineralization stems from the decrease in barite accumulation rates, where cooling could have caused a reduction in formation of barite due to weaker remineralization [Erhardt et al., 2013; Griffith et al., 2010] and the increase in organic matter burial [Olivarez Lyle and Lyle, 2006]. Diatoms, and in particular large diatoms, increased in abundance above Oi-1a in the Oligocene, suggesting a shift in silicic acid availability across this boundary, again potentially related to the nutrient source. Here we aim to use radiolarian nitrogen isotope records from the latest Eocene and Oi-1 to enhance our understanding of the underlying causes and consequences of the observed changes as they relate to nutrient dynamics.

Integrated Ocean Drilling Program (IODP) Site U1333 provides an excellent archive of Pacific Ocean and global climate histories across the Eocene-Oligocene climate transition [Erhardt et al., 2013]. However, the paucity of organic matter in these sediments precludes the use of traditional biomarker and isotopic proxies 
Table 1. Size Fractions Used for Microfossil-Bound $\delta{ }^{15} \mathrm{~N}$ for Surface Sediment and Eocene-Oligocene Investigations

\begin{tabular}{lcc} 
Size Fraction & Surface Sediment & Eocene-Oligocene \\
\hline$>125 \mu \mathrm{m}$ & Radiolarian & $\begin{array}{c}\text { Radiolarian (not used) } \\
\text { Radiolarian }\end{array}$ \\
$<63 \mu \mathrm{m}$ & Diatoms & Ralian \\
\hline
\end{tabular}

in biogeochemical evaluation efforts. Siliceous microfossils, present throughout these sediment sequences, are built on nitrogen-bearing organic templates [King, 1977; Kroger et al., 1999; Swift and Wheeler, 1992]. These organic molecules are encapsulated by biogenic silica and largely isolated from microbial alteration within the sediment column. Our approach of using biosilica as a $\mathrm{N}$ archive, using both modern surface sediment and Eocene core material, provides clear evidence for a robust fraction of $\mathrm{N}$ preserved within the opal biominerals from which reproducible $\delta^{15} \mathrm{~N}$ values can be measured. However, in the Oligocene, unlike modern eastern equatorial Pacific (EEP) sediment, particle size does not adequately separate diatoms from radiolarians. Diatoms are nearly absent in the Eocene and increase to become dominant in the early Oligocene, with significant contributions to both the large and small fractions [Baldauf, 2013]. We measured the $\delta^{15} \mathrm{~N}$ in the $<63 \mu \mathrm{m}$ radiolarian fraction and examine these data in the context of radiolarian species turnover (i.e., first and last appearance datums, from Moore et al. [2015]), relative contributions of diatoms and radiolarians, and biosiliceous valve preservation. Finally, we present first-order interpretations of the radiolarian $\delta^{15} \mathrm{~N}$ record across the Eocene-Oligocene boundary.

\section{Methods}

\subsection{Sediment Sampling}

Modern surface sediment samples $(0-5 \mathrm{~cm})$ were collected by multicorer from R/V Knorr on cruise KNR 195-3 in a transect along the equator between $93^{\circ} \mathrm{W}$ and $145^{\circ} \mathrm{W}$ in 2009 (Figure 1; http://gyre.gso.uri.edu/ robp/ EQP_site_reports2_09_opt.pdf). Samples from six locations were subsampled for measurement of microfossil-bound $\delta^{15} \mathrm{~N}(<63 \mu \mathrm{m}$ and $>125 \mu \mathrm{m})$ and bulk sediment $\delta^{15} \mathrm{~N}$ (Figure 1) [Schlitzer, 2013]. Annually averaged surface ocean nitrate concentrations overlying the multicore locations range from 4.4 to $8.1 \mu \mathrm{m}$; surface nitrate was upwelled at the equator and advected laterally. The $\delta^{15} \mathrm{~N}$ of subeuphotic zone nitrate is relatively uniform with a value of $7.1 \pm 0.3 \%$ o [Rafter et al., 2012]. The spatial variation in $\delta^{15} \mathrm{~N}$ values should reflect the progressive utilization of nitrate [Farrell et al., 1995; Robinson et al., 2009]. Smear slide examination indicates that the $>125 \mu \mathrm{m}$ fraction was dominated by radiolarian tests ( $>95 \%)$ with only a small contribution from large diatoms and diatom girdle bands. We will refer to it as the radiolarian fraction (Table 1). The $<63 \mu \mathrm{m}$ fraction was composed of diatom frustules (herein diatom fraction) with a small, but potentially important, contribution from radiolarians and radiolarian fragments $(\sim 10 \%)$. The $63-125 \mu \mathrm{m}$ fraction was a mixture of diatom and radiolarian fragments and was not measured.

Samples from IODP Site U1333B in the interval spanning late Eocene to earliest Oligocene were measured as a preliminary test of the radiolarian-bound $\delta^{15} \mathrm{~N}$ proxy in the ancient record. Site U1333 was drilled at $10.5^{\circ} \mathrm{N}$, $138.4^{\circ} \mathrm{W}$ in $4853 \mathrm{~m}$ of water (Figure 2). The paleolatitude of U1333 during the Eocene backtracks to $\sim 3^{\circ} \mathrm{N}$ at $35 \mathrm{Ma}$, just outside of the highest-productivity zone of the equatorial upwelling region [Shipboard Scientific Party, 2009]. Small ( $40 \mathrm{mg}$ ), dried bulk subsamples were analyzed for calcium carbonate content using a UIC coulometer for stratigraphic constraints. In the upper Eocene through the lower Oligocene glacial maximum Oi-1, biosilica came almost exclusively from radiolarians, with only small contributions from

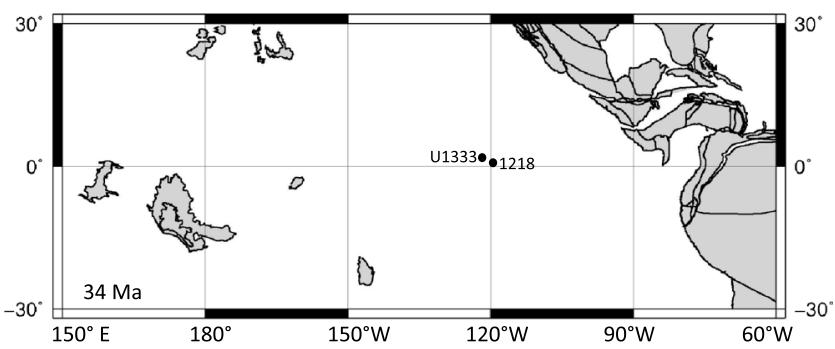

Figure 2. Site map showing backtracked locations of IODP Site U1333 and ODP Site 1218 at 34 Ma [Erhardt et al., 2013]. sponge spicules and diatoms [Baldauf, 2013; Moore et al., 2015]. Samples were sieved at $63 \mu \mathrm{m}$ for analysis. Our primary reason for sieving was to try to separate diatoms from radiolarians in the Oligocene; however, the early Oligocene, in particular the youngest part of the glaciation $\mathrm{Oi}-1 \mathrm{~b}$, is marked by significant occurrences of large diatoms, such that both fractions were mixtures of diatoms and radiolarians in the Oligocene [Moore et al., 2014]. The 


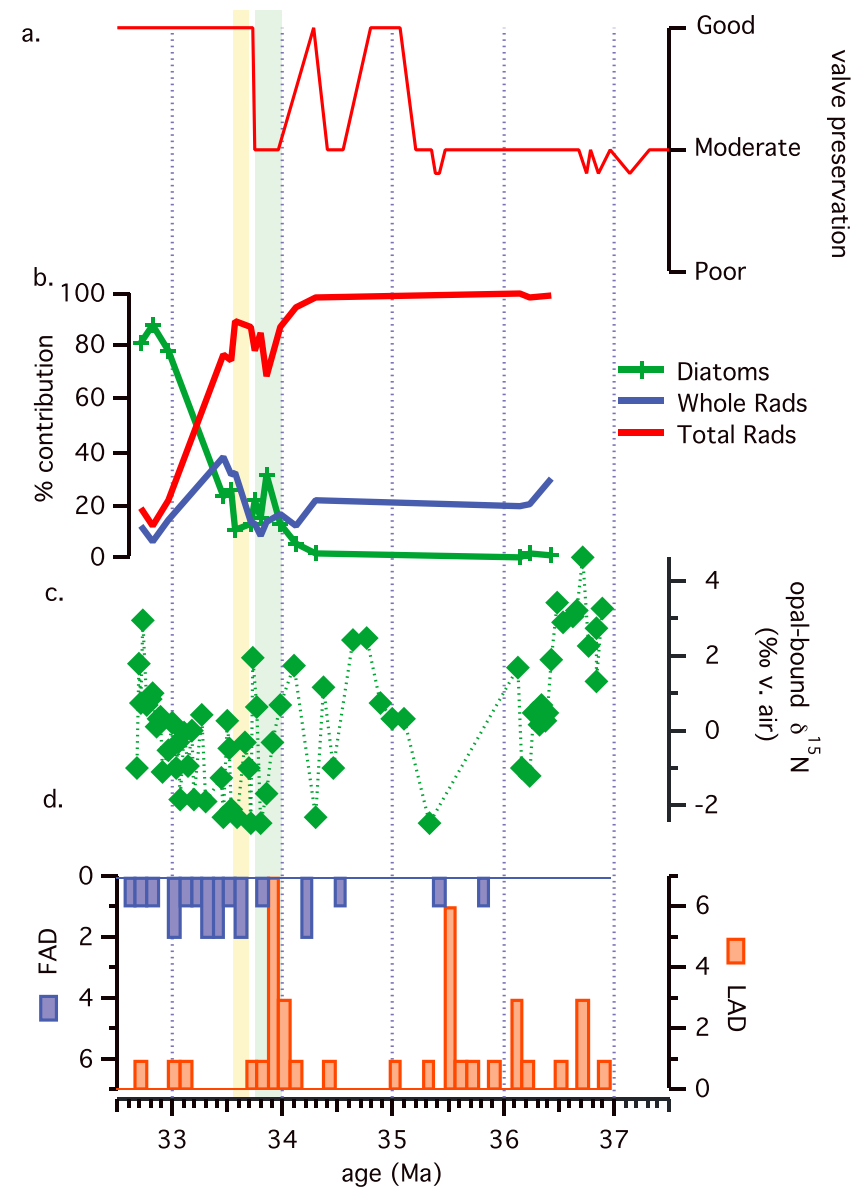

Figure 3. (a) Downcore records of valve preservation, (b) diatom and radiolarian contribution to the $<63 \mu \mathrm{m}$ fraction (relative percent), (c) radiolarianbound $\delta{ }^{15} \mathrm{~N}_{<63 \mu \mathrm{m}}$ values, and (d) radiolarian first and last occurrence (FAD and LAD, respectively) frequency data [Moore et al., 2015] plotted versus age at Site U1333 across the Eocene-Oligocene boundary [Westerhold et al., 2014]. The green bar highlights the Eocene-Oligocene climate transition. The yellow bar highlights early Oligocene glacial maximum (Oi-1). The gray shading marks samples that are a mixture of diatoms and radiolarians. permanganate oxidation, a reductive cleaning, and two hot perchloric acid oxidations. Additional modifications for the Eocene sediment were needed to ensure they were completely clean, including a second reductive cleaning and a third $70 \%$ hot $\left(100^{\circ} \mathrm{C}\right)$ perchloric acid cleaning. The additional reductive step was determined to be necessary by visual examination of sediment precleaning and postcleaning where the red tint of oxidized iron was still apparent after a single step. The additional perchloric acid step was added after cleaning tests demonstrated that $\delta^{15} \mathrm{~N}$ values were still variable after the two standard cleanings, but that a third application resulted in reproducible and stable values (Table 2). Clean, dry biosilica samples were dissolved and the organic $\mathrm{N}$ oxidized to nitrate using an alkaline persulfate reagent [Robinson et al., 2004]. Nitrate concentrations of the persulfate oxidized frustule $\mathrm{N}$ were measured by chemiluminescence after reduction to NO using a Teledyne Instruments (Model 200E) chemiluminescence $\mathrm{NO} / \mathrm{NO}_{x}$ analyzer [Braman and Hendrix, 1989]. $\delta^{15} \mathrm{~N}$ values were measured by gas chromatography-isotope ratio mass spectrometry (GC-IRMS) on a Thermo Delta V Advantage IRMS. Nitrate was converted to $\mathrm{N}_{2} \mathrm{O}$ for injection by the denitrifier method [Sigman et al., 2001]. The potassium nitrate reference material IAEA-N3, USGS 32, and USGS 34 (4.7\%o, $180 \%$, and $-1.8 \%$, respectively) was used to standardize $\delta^{15} \mathrm{~N}$ results. Precision was determined by multiple measurements of standards within each run and replicate measurements of samples. The standard error for these measurements was $0.4 \%$ o for the recent EEP samples and $0.7 \%$ or the ancient material. 
Table 2. Typical Cleaning Results From Trials With U1333 E/O Samples ${ }^{a, b}$

\begin{tabular}{ccc} 
Sample ID & $\begin{array}{c}\text { Initial Cleaning Result } \\
\left(\delta^{15} \mathrm{~N} \% \text { v. Air }\right)\end{array}$ & $\begin{array}{c}\text { Additional Perchloric } \\
\left(\delta^{15} \mathrm{~N} \% \text { v. Air }\right)\end{array}$ \\
\hline $320 \mathrm{U} 1333 \mathrm{~B} 12 \mathrm{H} 5$ & 3.2 & -0.52 \\
$37-39<63 \mu \mathrm{m}$ & 0.6 & -1.05 \\
$320 \mathrm{U} 1333 \mathrm{~B} 13 \mathrm{H} 5$ & 1.90 & 0.3 \\
$59-61<63 \mu \mathrm{m}$ & 0.4 & 0.3 \\
$320 \mathrm{U} 1333 \mathrm{~B} 13 \mathrm{H} 5$ & 0.7 & \\
$109-111<63 \mu \mathrm{m}$ & 0.6 & 2.2 \\
& 2.7 & 2.3 \\
\hline
\end{tabular}

${ }^{\mathrm{a}}$ Published cleaning with a single weak and single strong perchloric acid cleaning [Morales et al., 2013].

bublished cleaning [Morales et al., 2013] with additional 70\% perchloric acid cleaning step.

\section{Results and Discussion}

\subsection{Modern Sedimentary} Radiolarian-Bound N Isotope Values

Surface sedimentary bulk $\delta^{15} \mathrm{~N}$, diatombound $\delta^{15} \mathrm{~N}$, and radiolarian-bound $\delta^{15} \mathrm{~N}$ values all trace a similar pattern when plotted against longitude or In $\left[\mathrm{NO}_{3}{ }^{-}\right]$(Figure 1 and Table 1). The bulk sedimentary $\delta^{15} \mathrm{~N}$ values range from 4.1 to $7.9 \%$ and increase with decreasing annual mean $\left[\mathrm{NO}_{3}{ }^{-}\right.$]. Overall, the data are consistent with previous studies showing the spatial variability of sedimentary $\delta^{15} \mathrm{~N}$ in modern EEP sediments to be driven by the degree

of nitrate utilization [Farrell et al., 1995; Robinson et al., 2009]. Moreover, all three measured fractions (diatom, radiolarian, and bulk) record this increase, with approximately similar degrees of enrichment associated with decreasing nitrate concentrations. Estimates of the degree of isotopic fractionation during nitrate assimilation, as epsilon values $(\varepsilon)$ approximated from the slope of the line in the $\delta^{15} \mathrm{~N}$ versus $\ln \left[\mathrm{NO}_{3}{ }^{-}\right.$] plot, range from 4 to $6 \%$ depending upon which of the three proxy fractions you use (Figure 1). These values are in generally good agreement with field and experimental estimates of apparent $\varepsilon$ values during nitrate assimilation [Altabet, 2001]. Both the small and large biogenic silica fractions appear to be more sensitive to nutrient drawdown changes (higher $\varepsilon$ values) than bulk sediment.

Both microfossil-bound fractions have values lower than the bulk, with the diatom fraction falling 4-5\%o lower than bulk and the radiolarian fraction 2-2.5\%o lower than diatoms and 6-7.5\%o lower than bulk sediment (Table 3). In general, this is consistent with culture observations, where bulk diatom biomass is isotopically enriched relative to the microfossil-bound fraction [Horn et al., 2011b]. However, perplexingly, sedimentary diatom-bound $\delta^{15} \mathrm{~N}$ measurements do not show such large offsets between the bulk sediment and the microfossil-bound $\delta^{15} \mathrm{~N}$ values in Southern Ocean sediment [Horn et al., 2011a; Robinson et al., 2004, 2005; Robinson and Sigman, 2008] or in particulate samples from the Bering Sea [Morales et al., 2014]. The process behind this discrepancy remains unknown.

The additional offset to lower values from the small- to the larger-size fraction (i.e., diatoms versus radiolarians) is also consistent with observations where larger diatoms, radiolarians, and sponge spicules tend to record lower $\delta^{15} \mathrm{~N}$ values than the smaller/diatom fractions [Kalansky et al., 2011; Studer et al., 2013]. In Bering Sea sediment, this was attributed to contamination by large, very low $\delta^{15} \mathrm{~N}$ bearing fractions such as sponge spicules and radiolarians [Studer et al., 2013]. In Guaymas Basin (Gulf of California) sediments, where both the large- and small-size fractions are dominated by diatoms, this trend of lower values with larger-sized organisms was interpreted as a reflection of the depth preferences of the different diatom groups, where the larger diatoms may live at depth [Kalansky et al., 2011].

Table 3. Results From Surface Sedimentary Bulk, Diatom, and Radiolarian-Bound $\delta^{15} \mathrm{~N}$ Analyses ${ }^{\mathrm{a}}$

\begin{tabular}{lccccc} 
Sample ID/Longitude ${ }^{\circ} \mathrm{W}$ & $\begin{array}{c}\text { Bulk } \delta^{15} \mathrm{~N} \% \mathrm{v} . \\
\text { Air }\end{array}$ & $\begin{array}{c}\text { Diatom } \delta{ }^{15} \mathrm{~N} \% \text { v. } \\
\text { Air }\end{array}$ & $\begin{array}{c}\text { Rad } \delta^{15} \mathrm{~N} \% \text { v. } \\
\text { Air }\end{array}$ & $\begin{array}{c}\text { Diatom-Rad } \\
\Delta \delta^{15} \mathrm{~N}\end{array}$ & $\begin{array}{c}\text { Bulk-Rad } \\
\Delta \delta^{15} \mathrm{~N}\end{array}$ \\
\hline EQP 2/93 & 6.7 & 0.9 & -1.9 & 2.8 & 8.5 \\
EQP 3a/105 & 5.1 & -0.1 & -2.4 & 2.3 & 7.4 \\
EQP 4/113 & 5.9 & 2.4 & -0.2 & 2.6 & 6.1 \\
EQP 5/123 & 4.3 & 1 & -1.4 & 2.4 & 5.7 \\
EQP 6/131 & 6.1 & 1.0 & -1.4 & 2.2 & 7.5 \\
EQP 8/148 & 7.7 & 4.2 & 2.0 & 2.2 & 5.7 \\
MEAN & 5.9 & 1.5 & -0.9 & 2.4 & 7.1 \\
STDEV & 1.2 & 1.4 & 1.6 & 0.2 & 1.1 \\
\hline
\end{tabular}

${ }^{\mathrm{a}}$ The diatom-bound component was operationally defined as the $<63 \mu \mathrm{m}$ fraction of isolated biogenic silica and radiolarian bound as the $>150 \mu \mathrm{m}$ fraction of isolated biogenic silica. 
Our visual observations of the surface sediment sieved fractions, in smear slides, suggest that sieving excludes most of the radiolarians from the small fraction and diatoms from the large fraction and that spicules contribute minimally to both. This is also consistent with the good reproducibility of the offsets and spatial patterns. If the measured values were largely due to contamination by large sponge spicules, then one would expect higher variability in the overall data set and in particular in the radiolarian fraction. Instead, it appears that the offset observed here may be related either to ecology of the organisms (e.g., depth preference or the hosting of algal symbionts) or some intrinsic fractionation associated with the compounds affiliated with test formation.

The radiolarian-bound $\delta^{15} \mathrm{~N}$ values reflect changes in nitrate utilization, as do the bulk sediment and diatombound values. Thus, it appears that whatever the mechanism for organic matter incorporation, relative variations in the $\delta^{15} \mathrm{~N}$ value of the microfossil-bound organic matter reflect the $\delta^{15} \mathrm{~N}$ of the bulk organic matter and surface nitrate. Radiolarians are opportunistic feeders; they eat sinking detritus and microbial biomass growing on the sinking organics. It is expected that heterotrophic organic matter is enriched in ${ }^{15} \mathrm{~N}$, with an increase of 2-5\%o with each trophic position [DeNiro and Epstein, 1981; Macko and Estep, 1984]. This type of enrichment is apparent in the relatively high absolute $\delta^{15} \mathrm{~N}$ values recorded in (planktonic) foraminiferal-bound organic N [Martinez-Garcia et al., 2014; Ren et al., 2009]. But in contrast to planktonic foraminifera, the radiolarians record significantly lower $\delta^{15} \mathrm{~N}$ values than the source of their nutrition. One could speculate that microbial biomass may bear a lower $\delta^{15} \mathrm{~N}$ value, due to their use of the ammonium pool that results from preferential remineralization of low $\delta^{15} \mathrm{~N}$ biomass components during sinking [Macko et al., 1986; Robinson et al., 2012]. However, radiolarians are also likely to eat small heterotrophs, which should bear higher $\delta^{15} \mathrm{~N}$ values than phytoplankton biomass. More importantly, their diet is not likely to be significantly different from planktonic foraminifera. Instead, the low $\delta^{15} \mathrm{~N}$ values of radiolarian tests may be related to the compounds radiolarians make during test formation. That is to say, their biomass may be significantly enriched in ${ }^{15} \mathrm{~N}$, but the organic molecules associated with radiolarian tests are depleted such that the $\delta^{15} \mathrm{~N}$ values they record vary with the bulk organic matter field but with a large fractionation imparted during biomineralization. Perhaps, they utilize the isotopically light "waste" compounds that are otherwise excreted as a source of $\mathrm{N}$ for test formation. Answers to these questions are beyond the scope of the present study. Nevertheless, given the empirical observation that radiolarianbound $\delta^{15} \mathrm{~N}$ values parallel the $\delta^{15} \mathrm{~N}$ values of the bulk sediment in modern samples and are relatable to consumption of the surface nitrate pool, we moved forward with our analysis of ancient samples. Because of this relationship, the Eocene-Oligocene radiolarian-bound $\delta^{15} \mathrm{~N}$ values should be interpretable in the same way that bulk sedimentary $\delta^{15} \mathrm{~N}$ values are-as a reflection of near-surface nutrient nitrogen sources and supply and demand processes.

\subsection{Eocene-Oligocene Microfossil-Bound $\delta^{15} \mathrm{~N}$ Values}

The ancient tropical sediment samples were dominated by radiolarians throughout the upper Eocene and into the Oi-1 glacial event (Figure 3b). Diatoms supplanted radiolarians as the dominant biosiliceous fossils in the lower Oligocene, with significant contributions in both the large- and small-size fractions [Baldauf, 2013; Moore et al., 2014]. Preservation of radiolarian tests was moderate to good throughout the interval analyzed (Figure 3a). $\delta^{15} \mathrm{~N}_{<63} \mu \mathrm{m}$ values range from 4\%o near $36.8 \mathrm{Ma}$ to $-2 \%$ o during the early Oligocene glacial maximum (Figure 3), with an increase to $2 \%$ o upward in the Oligocene. Radiolarian turnover is enhanced in three intervals, $35.5,34$, and $33 \mathrm{Ma}$, with significant losses of radiolarian species and more subtle introduction of new groups [Funakawa et al., 2006; Moore et al., 2015]. These are also intervals where $\delta^{15} \mathrm{~N}$ values shift, suggesting possibly a radiolarian species related change in $\delta^{15} \mathrm{~N}$. However, the stepwise turnover in the late Eocene, characterized by a loss of tropical species and gain of cosmopolitan radiolarians, is not accompanied by a significant change in diversity where the most abundant species make up $15-35 \%$ of the total assemblage across the late Eocene and early Oligocene [Funakawa et al., 2006]. More likely, the radiolarian turnovers are signaling significant ecosystem changes that are paralleled by the $\delta^{15} \mathrm{~N}$ of the surface ocean inorganic and/or organic pools.

The emergence of diatoms as an important siliceous microfossil in the lower Oligocene complicates our interpretation of the upper portion of the record. Given that diatom-bound $\delta^{15} \mathrm{~N}$ values tend to be higher than radiolarian-bound $\delta^{15} \mathrm{~N}$ values, in our surface sediment survey (Figure 1) and elsewhere 
[Studer et al., 2013], we can estimate that the increase in $\delta^{15} \mathrm{~N}_{<63 \mu \mathrm{m}}$ values observed between 33.5 and $32.5 \mathrm{Ma}$ is in part due to the relative contributions of these two groups. However, quantitative corrections are hampered by a lack of data on relative contributions of nitrogen as well as a robust "offset" between the two groups. As a result, we focus on the upper Eocene and the Eocene-Oligocene transition, where radiolarians dominate the microfossil assemblage.

The first-order controls on sedimentary nitrogen isotope values in the modern and Pleistocene Equatorial Pacific are the isotopic composition of the nutrient source(s) and the relative consumption of nutrients in the surface ocean [Farrell et al., 1995; Rafter and Charles, 2012; Robinson et al., 2009]. Variation in the isotopic composition of source nitrate occurs both on orbital [Dubois et al., 2011; Rafter and Charles, 2012; Robinson et al., 2009] and million-year timescales [Robinson et al., 2014]. Variation in nutrient consumption appears to occur on orbital or suborbital timescales, such that it appears as systematic variation about the mean set by the source nitrate $\delta^{15} \mathrm{~N}$ value [Robinson et al., 2009, 2014]. Given the multimillion year interval being discussed and an average sampling resolution on the order of $20 \mathrm{ky}$, what we observed is likely a reflection of variation in the source $\delta^{15} \mathrm{~N}$ value with some overprinting by local consumption, if indeed nutrients were in excess in the Eocene. The observed range of $\delta^{15} \mathrm{~N}$ variation in the Eocene-Oligocene section is approximately the same as the observed range of $\delta{ }^{15} \mathrm{~N}_{\text {rad }}$ values in the modern surface sediment study. If the data were entirely controlled by nitrate utilization, it suggests a fairly moderate range of nitrate concentrations. However, our ability to interpret the Eocene data is limited by our understanding of the nutrient status of that epoch. We will limit our interpretations to first-order inferences related to source changes.

Using the modern offset between radiolarian-bound $\delta^{15} \mathrm{~N}$ values and the bulk sedimentary $\delta^{15} \mathrm{~N}$ value, $7.1 \pm 1.1 \%$, and the Eocene mean $\delta^{15} \mathrm{~N}_{<63 \mu \mathrm{m}}$ value, $0.5 \pm 2.0 \%$, we estimate that the bulk organic matter would possess an average $\delta^{15} \mathrm{~N}$ value of $\sim 7.6 \pm 3.1 \%$ o. This is within error of the measured mean bulk $\delta^{15} \mathrm{~N}$ value in the modern, surface EEP sediment $(5.9 \pm 1.2 \%$ ) and suggests that the nitrogen isotope systematics of the Eocene ocean were not significantly different than they are at present. There are important caveats associated with direct application of the modern isotopic offset to Eocene radiolarian-bound $\delta^{15} \mathrm{~N}$ given the fundamental differences in the ecosystem, including the lack of diatoms, a major part of the modern food web, the extreme warmth and lack of organic matter burial, which suggests rapid recycling of the sinking flux [Olivarez Lyle and Lyle, 2006; Palike et al., 2012], and the related overall lower export productivity of this time period relative to more modern times [Erhardt et al., 2013; Moore et al., 2014]. Keeping this in mind, we use this estimate only as a starting point.

\subsection{Explaining the Decrease in $\delta^{15} \mathrm{~N}$ Values Across the Eocene-Oligocene Boundary}

The observed decrease in $\delta^{15} \mathrm{~N}_{<63 \mu \mathrm{m}}$ values must be related to a decrease in the $\delta^{15} \mathrm{~N}$ of the sinking particulate organic matter. Such a change may be related to (1) a large-scale change in the $\delta^{15} \mathrm{~N}$ of nitrate, either globally or locally; (2) a decrease in the local utilization of nitrate; (3) a change in the source of nitrate upwelling in the EEP; or (4) a change in the $\delta^{15} \mathrm{~N}$ of the upwelling nitrate. It is unknown how the mean isotopic composition of the whole ocean nitrate pool, currently $\sim 5 \%$, varied in the past. Our best long-term estimate comes from a Phanerozoic-scale compilation of sedimentary $\delta^{15} \mathrm{~N}$ values where the mean in the Eocene is approximately the same as it is at present [Algeo et al., 2014]. However, it is not well constrained. If the observed decrease in $\delta^{15} \mathrm{~N}$ during the late Eocene and into the earliest Oligocene glacial maximum is related to a whole ocean change, then it suggests a shift in the balance of where denitrification occurs, i.e., in the sediment or the water column [Brandes et al., 1998; Deutsch et al., 2004]. Denitrification is the bacterial reduction of nitrate in the absence of oxygen, and it is a strongly fractionating process that leaves the remaining nitrate pool enriched in ${ }^{15} \mathrm{NO}_{3}{ }^{-}$when it occurs in the water column. In sediment, denitrification proceeds to completion, with little apparent fractionation measured in the overlying water [Brandes et al., 1998; Sigman et al., 2003]. A decrease in mean ocean $\delta^{15} \mathrm{~N}$ values implies more sedimentary relative to pelagic denitrification. The estimated $60 \mathrm{~m}$ of sea level fall across the second step of the Eocene-Oligocene transition (EOT, Figure 3), when $\delta^{15} \mathrm{~N}$ values are at an absolute minimum, suggests that shelf space for sedimentary denitrification worldwide decreased significantly across this interval [Christensen et al., 1987; Middelburg et al., 1996]. In this case, $\delta^{15} \mathrm{~N}$ values decrease as shelf space is reduced by falling sea level. A whole ocean $\delta^{15} \mathrm{~N}$ shift driven by an increase in 
a.

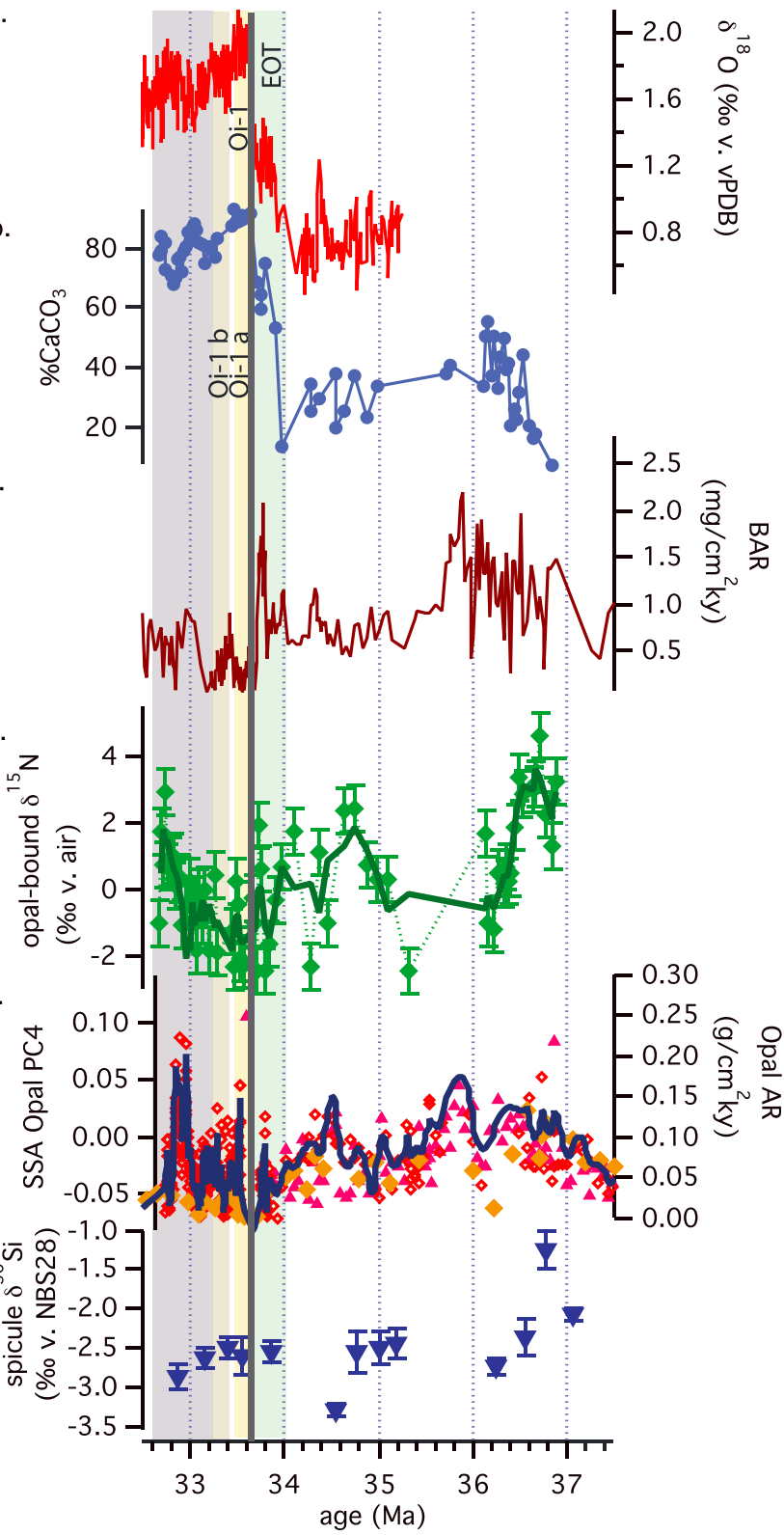

Figure 4. (a) Downcore records of benthic foraminiferal $\delta^{18} \mathrm{O}$ from ODP Site 1218 [Coxall et al., 2005], (b) $\mathrm{CaCO}_{3}$ content of bulk sediment from U1333B, (c) Barite Accumulation Rate [Erhardt et al., 2013], (d) opal-bound $\delta^{15} \mathrm{~N}_{<63} \mu \mathrm{m}$ from U1333B with error bars highlighting standard error of $\pm 0.7 \%$ and thick green line showing the five-point running mean, (e) opal AR from ODP 1218 [Moore et al., 2014], and (f) spicule $\delta^{30}$ Si values from ODP in the Southern Ocean [Egan et al., 2013]. As in Figure 2, the green bar highlights the Eocene-Oligocene climate transition and the yellow the early Oligocene glacial maximum (Oi-1). The thick line at 33.7 Ma marks the Eocene-Oligocene boundary. The gray shading marks samples that are a mixture of diatoms and radiolarians. vided the EEP with a new source nitrate to upwell. At present, the ultimate sources of nutrients upwelled in the EEP are a mixture of intermediate waters subducted in the Southern Ocean (Subantarctic Mode Water) and in the North Pacific (North Pacific Intermediate Water), with significant exchange with the eastern tropical Pacific (ETP) [Rafter et al., 2012; Toggweiler and Carson, 1995]. The opening of the Antarctic Gateways,

relative importance of sedimentary denitrification is thus unlikely. Alternatively, it is possible that an overall drop in nutrient availability and decrease in production allowed for significant input of $\mathrm{N}$ through diazotrophy. Nitrogen fixation would add $\mathrm{N}$ with a $\delta^{15} \mathrm{~N}$ value of $\sim-1 \%$ o to the system. To drive the entire $\sim 3 \%$ o shift, the addition would have had to be $\sim 50 \%$ of the total fixed $\mathrm{N}$, which again seems unlikely.

A decrease in $\delta^{15} \mathrm{~N}_{<63 \mu \mathrm{m}}$ could also be associated with a decrease in the relative utilization of nitrate as long as there were excess nitrate in the Eocene EEP. However, a decrease in $\delta^{15} \mathrm{~N}_{<63 \mu \mathrm{m}}$ would imply an increase in nutrient availability or weaker consumption. Typically, this type of nutrient-rich condition accompanies higher productivity in the EEP [Etourneau et al., 2013; Robinson et al., 2009]. The inferred drop in export productivity in the equatorial Pacific around the same time is therefore inconsistent with enhanced nutrient supply. More importantly, Plio-Pleistocene records of sedimentary $\delta^{15} \mathrm{~N}$ change in the EEP suggest that the long-term (million years) signal is largely controlled by the regional subsurface nitrate $\delta^{15} \mathrm{~N}$ rather than local nutrient consumption [Robinson et al., 2014].

On the other hand, circulation-driven changes in the source of nitrate or in the $\delta{ }^{15} \mathrm{~N}$ of the nitrate source are consistent with the other changes occurring in the latest Eocene and across the EOT. In the first case, the inferred new source of nitrate would bear a distinct $\delta^{15} \mathrm{~N}$ signature, as might be the case with a change in water mass geometry. In the second case, the source or water mass remains the same, but the nitrogen isotopic signature of that water mass would have changed, for example, with intensification/weakening of pelagic denitrification.

The inception of intermediate water formation and ventilation of the thermocline during cooling could have pro-

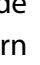

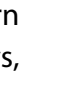


both the Tasman and Drake Passage, is thought to have allowed relatively deep waters to flow in the Antarctic Circumpolar Current (ACC) by the late Eocene [Cramer et al., 2009; Katz et al., 2011; Scher and Martin, 2006]. Once the ACC was established, a modern-like overturning structure was likely in place, including the upwelling of the deepest waters occurring in the Southern Ocean and the formation of nutrient-rich intermediate waters [Cramer et al., 2009; Egan et al., 2013; Katz et al., 2011]. The first decrease in $\delta^{15} \mathrm{~N}_{<63 \mu \mathrm{m}}$ values occurs at approximately $36.5 \mathrm{Ma}$. Sponge spicule silicon isotope data suggest an increase in Southern Ocean intermediate water nutrient content occurred around $36.5 \mathrm{Ma}$ as well [Egan et al., 2013]. If the $\delta^{15} \mathrm{~N}_{<63 \mu \mathrm{m}}$ change signals a new nutrient source to the EEP, it suggests that southern sourced intermediate water quickly became globally important. This is consistent with a modern-like overturning where intermediate water formation is fundamental part of the Southern Ocean circulation. Evidence in support of subsurface circulation change in the deep EEP comes from evidence of radiolarian reworking, where pulses of older radiolarian (on the order of parts per thousand) suggest the intrusion of dense bottom waters ( $\sim 3900 \mathrm{~m}$ paleodepth) initiating at $\sim 37 \mathrm{Ma}$, with later pulses at 35.3 Ma, 34.6 Ma, and again during the Oi-1 glaciation [Moore, 2013].

A regional decrease in the $\delta{ }^{15} \mathrm{~N}$ of nitrate delivered to EEP upwelling, without a significant change in the source of nutrients, is harder to diagnose. In the late Pleistocene, variation in the $\delta^{15} \mathrm{~N}$ of source nitrate to the EEP upwelling occurs on glacial-interglacial timescales [Rafter and Charles, 2012; Robinson et al., 2009]. The EEP sits adjacent to the major open ocean oxygen minimum zones (OMZ) of the ETP, and the $\delta^{15} \mathrm{~N}$ of nitrate in the EEP is overprinted by the isotopic signature of pelagic denitrification in the ETP [Rafter et al., 2012; Robinson et al., 2009]. The degree of deoxygenation of the Eocene ocean is uncertain as are the locations of Eocene oxygen minimum zones. Higher ocean temperatures and consequent lower solubility of oxygen likely reduced the mean oxygen content of the oceans in the Eocene. Without a strong ACC and the associated formation of cold, oxygen-rich intermediate water masses, interior ventilation may have been weaker as well [Katz et al., 2011]. Moreover, the reduced oxygen supply may have been coupled to higher demand, due to elevated export production [Erhardt et al., 2013; Griffith et al., 2010; Moore et al., 2014]. The trend, with a longterm decrease in $\delta^{15} \mathrm{~N}_{<63 \mu \mathrm{m}}$ values from an overall high around 36.5-37 Ma to the lowest values during the Oi-1 glacial maximum, is consistent with a regional weakening of pelagic denitrification due to cooling, enhanced ventilation, and/or the overall reduction in export productivity (Figure 4). Since the exact circulation pattern of the late Eocene is unclear [Martin and Scher, 2004; Thomas, 2004; Via and Thomas, 2006], predicting where and when an OMZ might expand or contract is presently impossible.

\section{Conclusions}

\subsection{Radiolarian $\mathbf{N}$ as an Isotopic Archive}

The modern radiolarian-bound $\delta^{15} \mathrm{~N}$ data suggest that radiolarian tests are a robust source of organic $\mathrm{N}$ for isotopic analysis and that their isotopic composition is related to the isotopic composition of the organic matter on which they fed. The large isotopic offset is consistent with previous investigations of radiolarianbound $\mathrm{N}$ and underscores the importance of separating this fraction from other opal microfossils for $\mathrm{N}$ isotope studies [Studer et al., 2013]. However, if the separation is quantitative, radiolarians have the potential to provide a nitrogen archive in regions of the ocean where bulk organics, diatoms, and foraminifers are less abundant or their records are discontinuous.

\section{2. $\mathbf{N}$ Isotopic Variation in the Eocene and Earliest Oligocene}

As a proof of concept, we presented radiolarian-bound $\delta^{15} \mathrm{~N}$ data from the late Eocene and initial glaciation of the Oligocene, when bulk organic matter contents and diatom contributions are too low to serve as reliable archives. We do not uniquely explain the observed changes in $\delta^{15} \mathrm{~N}$ in the EEP because of a lack of other constraints on the marine $\mathrm{N}$ cycle and accompanying isotope systematics during the time interval. The proposed explanations stem from climatic cooling and related changes in subsurface circulation. First, it is possible that the observed decrease in export productivity during the late Eocene and across the EOT accompanied a decrease in the extent of the Pacific OMZs and water column denitrification associated with enhanced ventilation of the ocean interior. Alternatively, the signal may reflect a fundamental shift in the water masses contributing to equatorial upwelling in the late Eocene, consistent with the inception of large-scale Southern Ocean overturning and intermediate water formation [Katz et al., 2011]. This explanation for the nitrogen isotope shifts fits well with the evidence for greater radiolarian turnover, 
toward cooler, more cosmopolitan fauna, in these intervals [Funakawa et al., 2006]. Finally, it is possible that the changes reflect local contributions to primary production by nitrogen fixers due to cooling and related deepening of the thermocline. Distinguishing between these explanations will require additional constraints on the large-scale Eocene $\mathrm{N}$ cycle and the role of ocean circulation in causing the observed decreases in production across the Eocene-Oligocene boundary. Radiolarian-bound nitrogen isotope measurements may provide an additional avenue for exploring these types of changes.

\section{Acknowledgments}

Thanks to Alissa Becker and C.J. Bascom for their assistance with radiolarianbound measurements. Dan MacDonald contributed significantly to the initial idea of measuring radiolarian $\mathrm{N}$ in the EEP. This work was supported by a USSSC postexpedition award to Robinson. Data are available through NOAA NCDC Paleoceanography Database (http://www.ncdc.noaa.gov/ data-access/paleoclimatology-data/ datasets/paleoceanography) and IODP (http://iodp.tamu.edu/tasapps/).

\section{References}

Algeo, T. J., P. A. Meyers, R. S. Robinson, H. Rowe, and G. Q. Jiang (2014), Icehouse-greenhouse variations in marine denitrification, Biogeosciences, $11,1$.

Altabet, M. (2001), Nitrogen isotopic evidence for micronutrient control of fractional $\mathrm{NO}_{3}{ }^{-}$utilization in the equatorial Pacific, Limnol. Oceanogr., 46, 368-380.

Altabet, M. A., and R. Francois (1994), Sedimentary nitrogen isotopic ratio as a recorder for surface nitrate utilization, Global Biogeochem. Cycles, 8(1), 103-116, doi:10.1029/93GB03396.

Baldauf, J. G. (2013), Data Report: Diatoms From Sites U1334 and U1338, Expedition 320/321, Integr. Ocean Drill. Program Manage. Int., Inc., Tokyo.

Braman, R. S., and S. A. Hendrix (1989), Nanogram nitrite and nitrate determination in environmental and biological-materials by Vanadium (III) reduction with chemi-luminescence detection, Anal. Chem., 61(24), 2715-2718.

Brandes, J. A., A. H. Devol, T. Yoshinare, D. A. Jayakumar, and S. W. A. Naqvi (1998), Isotopic composition of nitrate in the central Arabian Sea and eastern tropical North Pacific: A tracer for mixing and nitrogen cycles, Limnol. Oceanogr., 43, 1680-1689.

Christensen, J. P., D. W. Murray, A. Devol, and L. Codispoti (1987), Denitrification in continental shelf sediments has major impact on the oceanic nitrogen budget, Global Biogeochem. Cycles, 1(2), 97-116, doi:10.1029/GB001i002p00097.

Coxall, H. K., P. A. Wilson, H. Palike, C. H. Lear, and J. Backman (2005), Rapid stepwise onset of Antarctic glaciation and deeper calcite compensation in the Pacific Ocean, Nature, 433, 53-57.

Cramer, B. S., J. R. Toggweiler, J. D. Wright, M. E. Katz, and K. G. MIller (2009), Ocean overturning since the Late Cretaceous: Inferences from a new benthic foraminiferal isotope compilation, Paleoceanography, 24, PA4216, doi:10.1029/2008PA001683.

DeConto, R., and R. T. Pollard (2003), Rapid Cenozoic glaciation of Antarctica induced by declining atmospheric $\mathrm{CO}_{2}, \mathrm{Nature}, 421,245-247$.

DeConto, R., D. Pollard, P. A. Wilson, H. Palike, C. H. Lear, and M. Pagani (2008), Thresholds for Cenozoic bipolar glaciation, Nature, 455, doi:10.1038/nature07337.

DeNiro, M. J., and S. Epstein (1981), Influence of diet on the distribution of nitrogen isotopes in animals, Geochim. Cosmochim. Acta, 45, 341-351.

Deutsch, C., D. M. Sigman, R. C. Thunell, A. N. Meckler, and G. H. Haug (2004), Isotopic constraints on glacial/interglacial changes in the oceanic nitrogen budget, Global Biogeochem. Cycles, 18, GB4012, doi:10.1029/2003GB002189.

Diester-Haass, L. (1995), Middle Ecoene to early Oligocene paleoceanography of the Antarctic Ocean (Maud Rise, ODP Leg 113, Site 689): Change from a low to a high productivity ocean, Palaeogeogr. Palaeoclimatol. Palaeoecol., 113, 311-334.

Dubois, N., M. Kienast, S. Kienast, C. Normandeau, S. E. Calvert, T. Herbert, and A. Mix (2011), Millenial-scale variations in hydrography and biogeochemistry in the Eastern Equatorial Pacific over the last 100 ky, Quat. Sci. Rev., 30, 210-223.

Egan, K. E., R. E. M. Rickaby, K. R. Hendry, and A. N. Halliday (2013), Opening the gateways for diatoms primes Earth for Antarctic glaciation, Earth Planet. Sci. Lett., 375, 34-43.

Erhardt, A. M., H. Pälike, and A. Payton (2013), High-resolution record of export production in the eastern equatorial Pacific across the Eocene-Oligocene transition and relationships to global climatic records, Paleoceanography, 28, 130-142, doi:10.1029/2012PA002347.

Etourneau, J., R. S. Robinson, P. M. Martinez, and R. Schneider (2013), Large changes in upwelling intensity, biological production and nutrient utilization in the Eastern Equatorial Pacific over the last $3.2 \mathrm{Ma}$, Biogeosciences, 10, 5663-5670.

Farrell, J. W., T. F. Pedersen, S. E. Calvert, and B. Nielsen (1995), Glacial-interglacial changes in nutrient utilization in the equatorial Pacific Ocean, Nature, 377, 514,516.

Francois, R., M. A. Altabet, E.-F. Yu, D. M. Sigman, M. P. Bacon, M. Frank, G. Bohrmann, G. Bareille, and L. D. Labeyrie (1997), Contributions of Southern Ocean surface-water stratification to low atmospheric $\mathrm{CO}_{2}$ concentrations during the last glacial period, Nature, 389, 929-935.

Funakawa, S., H. Nishi, T. C. Moore, and C. Nigrini (2006), Radiolarian faunal turnover and paleoceanographic change around Eocene/Oligocene boundary in the central equatorial Pacific, ODP Leg 199, Holes 1218A, 1219A, and 1220A, Palaeogeogr. Palaeoclimatol. Palaeoecol., 230, 183-203.

Galbraith, E. D., D. M. Sigman, R. S. Robinson, and T. F. Pedersen (2008), Past changes in the marine nitrogen cycle, in Nitrogen in the Marine Environment, edited by D. G. Capone et al., pp. 1497-1535, Academic Press, San Diego, Calif.

Garcia, H. E., R. A. Locarnini, T. P. Boyer, J. I. Antonov, M. M. Zweng, O. K. Baranova, and D. R. Johnson (2010), World Ocean Atlas 2009 Volume 4 Nutrients (Phosphate, Nitrate, Silicate), 26 pp., Ocean Climate Lab., Natl. Oceanogr. Data Center, Silver Spring, Md.

Griffith, E., M. Calhoun, E. Thomas, K. B. Averyt, A. M. Erhardt, T. J. Bralower, M. Lyle, A. Olivarez Lyle, and A. Paytan (2010), Export productivity and carbonate accumulation in the Pacific Basin at the transition from a greenhouse to icehouse climate (late Eocene to early Oligocene), Paleoceanography, 25, PA3212, doi:10.1029/2010PA001932.

Horn, M., C. P. Beucher, R. S. Robinson, and M. Brzezinski (2011a), Nitrogen and silicon dynamics during the last deglaciation, Earth Planet. Sci. Lett., 310, 334-339.

Horn, M., R. S. Robinson, T. A. Rynearson, and D. Sigman (2011b), Nitrogen isotopic relationship between diatom-bound and bulk organic matter of cultured polar diatoms, Paleoceanography, 26, PA3208, doi:10.1029/2010PA002080.

Kalansky, J., R. S. Robinson, and B. N. Popp (2011), Insights into nitrogen cycling in the western Gulf of California from the nitrogen isotopic composition of diatom-bound organic matter, Geochem. Geophys. Geosyst., 12, Q06015, doi:10.1029/2010GC003437.

Katz, M. E., B. S. Cramer, J. R. Toggweiler, G. Esmay, C. Liu, K. G. Miller, Y. Rosenthal, B. S. Wade, and J. D. Wright (2011), Impact of Antarctic Circumpolar Current development on Late Paleogene ocean structure, Science, 332, 1076-1078.

King, K., Jr. (1977), Amino acid survey of recent calcareous and siliceous deep-sea microfossils, Micropaleontology, 23(2), $180-193$.

Kroger, N., R. Deutzmann, and M. Sumper (1999), Polycationic peptides from diatom biosilica that direct silica nanosphere formation, Science, 286(5442), 1129-1132. 
Macko, S. A., and M. L. F. Estep (1984), Microbial alteration of stable nitrogen and carbon isotopic compositions of organic matter, Org. Geochem., 6, 787-790.

Macko, S. A., M. L. Fogel, M. H. Engel, and P. E. Hare (1986), Kinetic fractionation of stable nitrogen isotopes during amino acid transamination, Geochim. Cosmochim. Acta, 50, 2143-2146.

Martin, E. E., and H. D. Scher (2004), Preservation of seawater Sr and Nd isotopes in fossil fish teeth: Bad news and good news, Earth Planet. Sci. Lett., 220(1-2), 25-39.

Martinez-Garcia, A., D. M. Sigman, H. Ren, R. F. Anderson, M. Straub, D. Hodell, S. L. Jaccard, T. I. Eglinton, and G. H. Haug (2014), Iron fertilization of the Subantarctic Ocean during the Last Ice Age, Science, 343, 1347-1350.

Middelburg, J. J., K. Soetaert, P. M. J. Herman, and C. H. R. Heip (1996), Denitrification in marine sediments: A model study, Global Biogeochem. Cycles, 10(4), 661-673, doi:10.1029/96GB02562.

Moore, T. C. (2013), Erosion and reworking of Pacific sediments near the Eocene-Oligocene boundary, Paleoceanography, 28, 263-273, doi:10.1002/palo.20027.

Moore, T. C., B. S. Wade, T. Westerhold, A. M. Erhardt, H. K. Coxall, J. Baldauf, and M. Wagner (2014), Equatorial Pacific productivity changes near the Eocene-Oligocene boundary, Paleoceanography, 29, 825-844, doi:10.1002/2014PA002656.

Moore, T. C., Jr., S. Kamikuri, A. M. Erhardt, J. Baldauf, H. K. Coxall, and T. Westerhold (2015), Radiolarian stratigraphy near the Eocene-Oligocene boundary, Mar. Micropaleontol., 116, 50-62.

Morales, L. V., D. M. Sigman, M. G. Horn, and R. S. Robinson (2013), Cleaning methods for the isotopic determination of diatom bound nitrogen in non-fossil diatom frustules, Limnol. Oceanogr. Methods, 11, 101-112.

Morales, L. V., J. Granger, B. X. Chang, M. Prokopenko, B. Plessen, R. Gradinger, and D. M. Sigman (2014), Elevated 15N/14N in particulate organic matter, zooplankton, and diatom frustule-bound nitrogen in the ice-covered water column of the Bering Sea eastern shelf, Deep Sea Res., Part II, 109, 100-111.

Olivarez Lyle, A., and M. Lyle (2006), Organic carbon and barium in Eocene sediments: Possible controls on nutrient recycling in the Eocene equatorial Pacific Ocean, in Proceedings of the Ocean Drilling Program, Scientific Results, edited by P. A. Wilson et al., Ocean Drill. Program, College Station, Tex.

Pagani, M., J. C. Zachos, K. H. Freeman, B. Tipple, and S. Bohaty (2005), Marked decline in atmospheric carbon dioxide concentrations during the Paleogene, Science, 309, 600-603.

Palike, H., et al. (2012), A Cenozoic record of the equatorial Pacific carbonate compensation depth, Nature, 488(7413), 609-614.

Pearson, P. N., G. L. Foster, and B. S. Wade (2009), Atmospheric carbon dioxide through the Eocene-Oligocene climate transition, Nature, 46, 1110-1113, doi:10.1038/nature08447.

Rafter, P. A., and C. Charles (2012), Pleistocene equatorial Pacific dynamics inferred from the zonal asymmetry in sedimentary nitrogen isotopes, Paleoceanography, 27, PA3102, doi:10.1029/2012PA002367.

Rafter, P. A., D. M. Sigman, C. D. Charles, J. Kaiser, and G. H. Haug (2012), Subsurface tropical Pacific nitrogen isotopic composition of nitrate: Biogeochemical signals and their transport, Global Biogeochem. Cycles, 26, GB1003, doi:10.1029/2010GB003979.

Ren, H., D. Sigman, A. N. Meckler, B. Plessen, R. S. Robinson, Y. Rosenthal, and G. H. Haug (2009), Foraminiferal isotope evidence of reduced nitrogen fixation in the Ice Age Atlantic Ocean, Science, 323, 244-248.

Ren, H., B. G. Brunelle, D. M. Sigman, and R. S. Robinson (2013), Diagenetic aluminum uptake into diatom frustule and preservation of diatom-bound organic nitrogen, Mar. Chem., 155, 92-101.

Robinson, R. S., and D. Sigman (2008), Nitrogen isotopic evidence for a poleward decrease in surface nitrate within the Ice Age Antarctic, Quat. Sci. Rev., 27, 1076-1090.

Robinson, R. S., B. G. Brunelle, and D. M. Sigman (2004), Revisiting nutrient utilization in the glacial Antarctic: Evidence from a new diatom-bound N isotope method, Paleoceanography, 19, PA3001, doi:10.1029/2003PA000996.

Robinson, R. S., D. M. Sigman, P. J. DiFiore, M. M. Rohde, T. A. Mashiotta, and D. W. Lea (2005), Diatom-bound ${ }^{15} \mathrm{~N} /{ }^{14} \mathrm{~N}$ : New support for enhanced nutrient consumption in the Ice Age Subantarctic, Paleoceanography, 20, PA3003, do:10.1029/2004PA2004001114.

Robinson, R. S., P. Martinez, L. D. Pena, and I. Cacho (2009), Nitrogen isotopic evidence for deglacial changes in nutrient supply in the eastern equatorial Pacific, Paleoceanography, 24, PA4213, doi:10.1029/2008PA001702.

Robinson, R. S., et al. (2012), A review of nitrogen isotopic alteration in marine sediments, Paleoceanography, 27, PA4203, doi:10.1029/2012PA002321.

Robinson, R. S., J. Etourneau, P. M. Martinez, and R. Schneider (2014), Expansion of water column denitrification during early Pleistocene cooling, Earth Planet. Sci. Lett., 389, 52-61.

Salamy, K. A., and J. C. Zachos (1999), Latest Eocene-Early Oligocene climate change and Southern Ocean fertility: Inferences from sediment accumulation and stable isotope data, Palaeogeogr. Palaeoclimatol. Palaeoecol., 145, 61-77.

Scher, H. D., and E. E. Martin (2006), Timing and climatic consequences of the opening of the Drake Passage, Science, 312, 428-430.

Schlitzer, R. (2013), Ocean Data View edited. [Available at http://odv.awi.de.]

Shipboard Scientific Party (2009), Initial Reports of Integrated Ocean Drilling Program Expeditions 320/321, edited by H. Palike et al., Integr. Ocean Drill. Program, College Station, Tex.

Sigman, D. M., M. A. Altabet, R. Francois, D. C. McCorkle, and J.-F. Gaillard (1999), The isotopic composition of diatom-bound nitrogen in Southern Ocean sediments, Paleoceanography, 14(2), 118-134, doi:10.1029/1998PA900018.

Sigman, D. M., K. L. Casciotti, M. Andreani, C. Barford, M. Galanter, and J. K. Böhlke (2001), A bacterial method for the nitrogen isotopic analysis of nitrate in seawater and freshwater, Anal. Chem., 73, 4145-4153.

Sigman, D. M., R. Robinson, A. N. Knapp, A. van Geen, D. C. McCorkle, J. A. Brandes, and R. C. Thunell (2003), Distinguishing between water column and sedimentary denitrification in the Santa Barbara Basin using the stable isotopes of nitrate, Geochem. Geophys. Geosyst., 4(5), 1040, doi:10.1029/2002GC000384.

Straub, M., D. M. Sigman, H. Ren, A. Martinez-Garcia, A. N. Meckler, M. P. Hain, and G. H. Haug (2013), Changes in North Atlantic nitrogen fixation controlled by ocean circulation, Nature, 501, 200-203, doi:10.1038/nature12397.

Studer, A., K. K. Ellis, S. Oleynik, D. M. Sigman, and G. H. Haug (2013), Size-specific opal-bound nitrogen isotopic measurement in North Pacific sediments, Geochim. Cosmochim. Acta, 120, 179-194.

Swift, D. M., and A. P. Wheeler (1992), Evidence of an organic matrix from diatom biosilica, J. Phycology, 28, 202-209.

Thomas, D. J. (2004), Evidence for deep-water production in the North Pacific Ocean during the early Cenozoic warm interval, Nature, 430, 65-68. Toggweiler, J. R., and S. Carson (1995), What are the Upwelling Systems Contributing to the Ocean's Carbon and Nutrient Budgets?, John Wiley, New York.

Via, R. K., and D. J. Thomas (2006), Evolution of Atlantic thermohaline circulation: Early Oligocene onset of deep-water production in the North Atlantic, Geol. Soc. Am., 34(6), 441-444.

Westerhold, T., U. Rohl, H. Palike, R. Wilkens, P. A. Wilson, and G. Acton (2014), Orbitally tuned timescale and astronomical forcing in the middle Eocene to early Oligocene, Clim Past, 10, 955-973. 